S. M. Bernasconi · P. A. Meyers · G. O'Sullivan

\title{
Early diagenesis in rapidly accumulating sediments on the Alboran slope, ODP site 976
}

Received: 27 October 1997 / Revision received: 4 March 1998

\begin{abstract}
The oxidation and reduction that occur during early diagenesis of sediments has been studied in the interstitial waters of a rapidly accumulating sedimentary sequence from the Mediterranean margin of Spain. A series of reactions that are mediated by progressively lower free energy derived from oxidation of organic matter is evident in the sedimentary sequence. Iron and manganese are rapidly reduced. Phosphate and alkalinity maxima at a subbottom depth of $15 \mathrm{~m}$ indicate maximal organic matter degradation. Methane first appears at $\sim 20 \mathrm{~m}$ subbottom after sulfate is depleted, and its concentrations quickly climb.
\end{abstract}

\section{Introduction}

Geochemical processes that occur in marine sediments impact the sea floor-seawater exchange of soluble elements and the subsequent composition of sediments. Postdepositional oxidation of sedimentary organic matter is central to many of these processes. The oxidation of organic matter follows a general sequence of terminal electron acceptors of, from first to last, interstitial oxygen, nitrate, $\mathrm{Mn}(\mathrm{IV})$ oxides, $\mathrm{Fe}(\mathrm{III})$ oxides, and sulfate (Froelich et al. 1979; Schulz et al. 1994) in the transition from oxic-suboxic-anoxic sediment conditions. Various

Stefano M. Bernasconi

Geologische Institut, ETH-Zentrum, CH-8092 Zürich, Switzerland

Philip A. Meyers ( $\square$ )

Marine Geology and Geochemistry Program, Department of Geological Sciences, The University of Michigan, Ann Arbor, Michigan 48109-1063, USA

Gerard O'Sullivan

Marine Geosciences Research Group, Department of Earth Sciences, University of Wales Cardiff, Cardiff CF1 3YE, UK mineral dissolution and precipitation processes occur during this sequence (Berner 1980; von Breymann et al. 1990; Canfield 1993) and affect sediment properties. For example, Torii (1997) documents changes in magnetic susceptibility of sediments that accompany dissolution of magnetite and maghemite. The interplay of oxidizing and reducing conditions also influences the mobilities of many metals (Wilson et al. 1986; Pruysers et al. 1993; Thomson et al. 1993). Moreover, evolution of interstitial dissolved $\mathrm{CO}_{2}$ from oxidation of organic matter increases in situ dissolution of $\mathrm{CaCO}_{3}$ (Emerson and Bender 1982; Berelson et al. 1990).

We have studied the oxidation and reduction that occur during early diagenesis of a rapidly accumulating sedimentary sequence. This expanded sequence, a turbiditic unit on the southern margin of Iberia, provides good resolution of the biogeochemical changes that occur to sedimentary constituents. Our data provide information about the interactions of redox-sensitive constituents of interstitial water and bulk sedimentary organic matter in the course of diagenetic alterations.

\section{Sampling and analysis}

\section{Depositional settings}

Sediments for this study were obtained from Ocean Drilling Program (ODP) site 976, which is located on the southern Iberian continental slope at a water depth of $1108 \mathrm{~m}$ in the Western Alboran Basin (Fig. 1). PliocenePleistocene sediments at this site consist of hemipelagic nannofossil-rich clay, nannofossil clay, and nannofossil silty clay (Comas et al. 1996). Their sedimentation rate averages $23 \mathrm{~cm} / \mathrm{ka}$, which is about 10 times the typical deep-sea sedimentation rate (Kennett 1982, p. 464). The elevated rate reflects delivery of sediments to this site by a combination of repetitive turbidity flows and settling of pelagic sediments. 
Fig. 1 Location of Ocean Drilling Program site 976 on the southern Iberian continental slope at a water depth of $1108 \mathrm{~m}$ in the Western Alboran Basin. Other nearby Ocean Drilling Program sites are shown

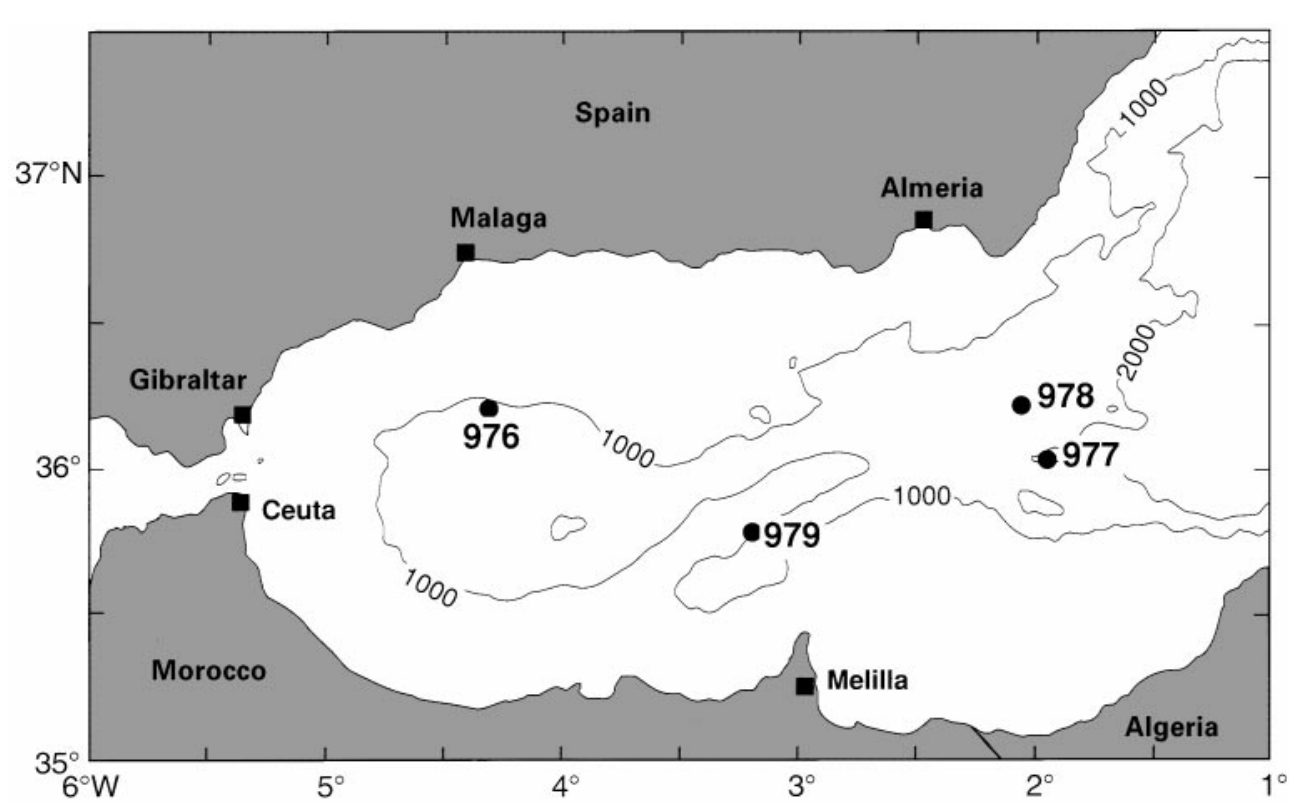

Upper Pleistocene sediment samples for porewater analysis and headspace gas analysis were collected at frequencies of one per $1.5-\mathrm{m}$ core section for the upper $40 \mathrm{~m}$ below sea floor (mbsf) and one per 9-m core from 40 to $70 \mathrm{mbsf}$. The total $70-\mathrm{m}$ sedimentary sequence represents approximately $300 \mathrm{ka}$ of burial time, with individual sediment samples ranging between ca. $6.5 \mathrm{ka}(1.5 \mathrm{mbsf})$ to $300 \mathrm{ka}(70 \mathrm{mbsf})$ in age.

\section{Interstitial water analyses}

Concentrations of selected cations and anions in the interstitial water of sediment samples were determined by squeezing $5-\mathrm{cm}$ whole-round intervals of cores immediately after their arrival on deck of the D/V JOIDES Resolution. A titanium squeezer, modified from the stainless steel squeezer of Manheim and Sayles (1974), was used to minimize chemical interactions between the constituents of the interstitial water and the metal of the squeezer. Water forced out of the sediment was collected in polyethylene syringes, filtered through 0.45 Gelman polysulfone filters, and stored in plastic vials until analysis.

A variety of the interstitial water constituents that are sensitive to early diagenesis were analyzed using standard ODP procedures (Gieskes et al. 1991) that are summarized here. Iron and manganese concentrations were quantified by flame atomic absorption spectrometry using a Varian SpectrAA-20. Sulfate concentrations were determined by ion chromatography using a Dionex DX-100 instrument. Phosphate and ammonium concentrations were measured spectrophotometry with a Milton Roy Spectronic 20 spectrophotometer. Alkalinity was measured by Gran titration with a Metrohm autotitrator.
Concentrations of calcium and magnesium were determined by titration.

\section{Headspace methane concentrations}

Samples for headspace gas analyses were taken immediately after each sediment core arrived on deck. A sample of approximately $5 \mathrm{~cm}^{3}$ of sediment was removed from the end of a freshly cut core section and placed in a glass vial that was then crimp-sealed with a rubber septum. The septum-sealed glass vials were heated at $70^{\circ} \mathrm{C}$ for $30 \mathrm{~min}$. A $5-\mathrm{cm}^{3}$ sample of headspace gas was drawn into a syringe and injected into a Hewlett-Packard 5890 II gas chromatograph equipped with a Haysep (80-100 mesh) packed column and a flame ionization detector. After the headspace gas had been analyzed, the sediment plugs were dried and weighed in preparation for subsequent determinations of carbon concentrations. Methane concentrations are normalized to a nominal 5-g sample of dry sediment to compensate for variations in actual sample masses.

\section{Organic carbon measurements and $\mathrm{C} / \mathrm{N}$ ratios}

The total organic carbon contents (TOC) were determined by the difference between total carbon concentrations as measured by a Carlo Erba NA 1500 NCS analyzer (Verardo et al. 1990) and the carbonate carbon concentrations as measured by a Coulometrics 5011 inorganic carbon analyzer (Engleman et al. 1985). Freeze-dried samples were combusted at $1000^{\circ} \mathrm{C}$ in an oxygen atmosphere in the NCS analyzer, and the resulting combustion products 
were chromatographically separated and quantified to yield the concentrations of total carbon and nitrogen. The differential TOC concentration procedure used in our study has been tested against the direct-determination analysis of carbonate-free sediment samples by Meyers and Silliman (1996). Agreement is good above TOC concentrations of $0.1 \%$. The TOC and total nitrogen values were used to calculate atomic $\mathrm{C} / \mathrm{N}$ ratios of the samples.

The $\mathrm{C} / \mathrm{N}$ ratios were used to distinguish between algal and land-plant origins of sedimentary organic matter. Algae typically have atomic $\mathrm{C} / \mathrm{N}$ ratios between 4 and 10 , whereas vascular land plants have $\mathrm{C} / \mathrm{N}$ ratios of 20 and greater (Premuzic et al. 1982; Emerson and Hedges 1988; Jasper and Gagosian 1990; Meyers 1994; Prahl et al. 1994). This distinction arises from the absence of cellulose in algae and its abundance in vascular plants, and it is largely preserved in sedimentary organic matter (Jasper and Gagosian 1990; Meyers 1994).

\section{Results and discussion}

The classic series of diagenetic reactions that are mediated by progressively lower free energy derived from oxidation of organic matter (Froelich et al. 1979; Schulz et al. 1994) is evident in the sedimentary sequence at site 976. The elevated sedimentation rate expands the effects of the series of biogeochemical alterations over much of the upper $70 \mathrm{~m}$ of the sediment column.

\section{Redox profiles}

Concentrations of $\mathrm{Fe}^{2+}$ and $\mathrm{Mn}^{2+}$ in the interstitial water decrease rapidly from $1.5 \mathrm{mbsf}$ (Fig. 2), indicating that the reduction zones for iron and manganese lie above this depth. The elevated concentrations of $\mathrm{Fe}^{2+}$ and $\mathrm{Mn}^{2+}$ in the uppermost sample indicate that oxidation of organic matter has reduced $\mathrm{Fe}$ and $\mathrm{Mn}$ in the surficial sediments. These data agree with the findings of Torii (1997), who determined that the minerological iron redox boundary coincides with a tan-green color transition at $1.2 \mathrm{mbsf}$ in site 976 sediments. The decreases in interstitial concentrations in deeper sediments show that ferrous and manganous ions evidently are readily absorbed from the interstitial waters by solid phase components of the sediments. Nitrate concentrations were not determined inasmuch as the $\mathrm{NO}_{3}^{-}$reduction zone is located stratigraphically above those of $\mathrm{Fe}$ and $\mathrm{Mn}$ (Froelich et al. 1979), and the reduced states of these cations indicate that nitrate reduction occurred very quickly in this sediment column.

Oxidation of organic matter after reduction of $\mathrm{Fe}^{3+}$ and $\mathrm{Mn}^{4+}$ ceases is done by reduction of sulfate (Froelich et al. 1979; Schulz et al. 1994), which consumes dissolved sulfate and releases a number of species that are derived from organic matter. This interchange is described by the general reaction:

$$
\begin{aligned}
& \left(\mathrm{CH}_{2} \mathrm{O}\right)_{106}\left(\mathrm{NH}_{3}\right)_{16}\left(\mathrm{H}_{3} \mathrm{PO}_{4}\right)+53 \mathrm{SO}_{4}^{2-} \rightarrow \\
& 106 \mathrm{HCO}_{3}^{-}+53 \mathrm{HS}^{-}+16 \mathrm{NH}_{3}+\mathrm{H}_{3} \mathrm{PO}_{4}+53 \mathrm{H}^{-}
\end{aligned}
$$

Concentrations of dissolved sulfate decrease progressively from seawater concentrations $(\sim 29 \mathrm{mM})$ and reach essentially zero by 20 mbsf (Fig. 2). This sediment depth corresponds to ca. $90 \mathrm{ka}$. The decrease in sulfate concentrations is accompanied by increases in concentrations of dissolved $\mathrm{PO}_{4}^{3-}$ and $\mathrm{NH}_{4}^{-}$, verifying that sulfate reduction is the major process involved in organic matter oxidation over this depth range. Moreover, the broad maximum in phosphate concentrations between 12.5 and 20.5 mbsf records the zone of maximum organic matter degradation.
Fig. 2 Redox-sensitive changes in concentrations of total iron, manganese, sulfate, phosphate, and ammonia in interstitial water samples from site 976. Sediment depths are given in meters below seafloor (mbsf)

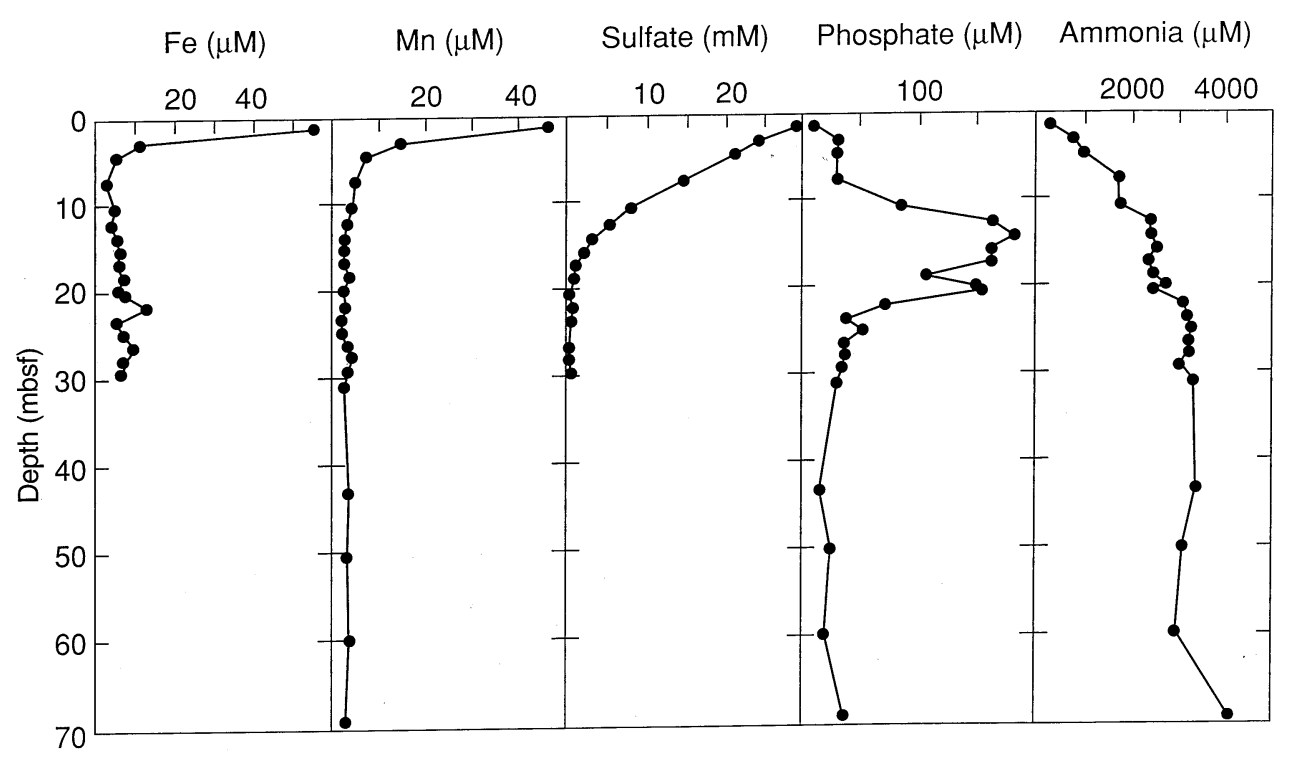




\section{Carbonate diagenesis}

The $\mathrm{CaCO}_{3}$ content of sediments from the upper $70 \mathrm{~m}$ at site 976 averages $25.5 \pm 3.8 \%$ and does not change systematically with depth (Fig. 3). Good preservation of nannofossils indicates that little carbonate dissolution has occurred in these sediments (Comas et al. 1996). Nonetheless, early diagenesis has created changes in interstitial water constituents that participate in carbonate equilibria.

A broad maximum in the alkalinity of the interstitial water between 10.5 and $20.5 \mathrm{mbsf}$ follows the dissolved phosphate profile and reflects the release of $\mathrm{CO}_{2}$ from oxidation of organic matter during sulfate reduction (Fig. 3). Böttcher et al. (1998) report $\delta^{13} \mathrm{C}$ values of dissolved inorganic carbon (DIC) that are more negative than seawater in these sediments. Values decrease from $-10.7 \%$ at $1.3 \mathrm{mbsf}$ to $-17.8 \%$ to $-19.1 \%$ from 10.5 to $29.4 \mathrm{mbsf}$ (Fig. 3). These negative DIC values confirm the oxidation of organic matter, which adds isotopically light organic carbon to the interstitial $\mathrm{CO}_{2}$ and is accompanied by increases in alkalinity and in phosphate concentrations (Fig. 2).

Concentrations of both $\mathrm{Ca}^{2+}$ and $\mathrm{Mg}^{2+}$ in the interstitial water decrease with depth. The decreases of these two cations may result from in situ precipitation of high magnesium calcite or possibly dolomite, or they may indicate cation exchange with clay minerals during early diagenesis. Because systematic changes are not evident in the sediment $\mathrm{CaCO}_{3}$ content, interaction with clay minerals seems the more likely possibility. The magnitudes of the changes in concentrations of $\mathrm{Ca}^{2+}$ and $\mathrm{Mg}^{2+}$, however, are small, so any increases in the mass of sedimentary $\mathrm{CaCO}_{3}$ would be masked by the large difference in relative sizes of the dissolved and solid phases.

\section{Organic matter oxidation}

In contrast to the redox-sensitive constituents of the interstitial waters and like the $\mathrm{CaCO}_{3}$ content of the solid phase, TOC concentrations of the bulk sediment do not systematically change over the $70-\mathrm{m}$ interval. The mean TOC is $0.7 \pm 0.2 \%$, and the range of concentrations is from $0.4 \%$ to $1.1 \%$. These sediments contain over twice as much organic carbon as the average of $0.3 \%$ compiled by McIver (1975) from DSDP legs 1-33, which can be taken as representative of deep-sea sediments. The TOC concentrations evidently are adequate to conceal the oxidation of organic matter implied by the changes in redox-sensitive constituents. This observation implies that only a small fraction of the available sedimentary organic matter need be oxidized to have significant impact on redox processes. It is also noteworthy that the variability in TOC concentrations (Fig. 4), which probably reflects the initial turbiditic emplacement of this sediment sequence, is not mirrored in the distributions of the dissolved constituents (Figs. 2 and 3), which are to a large degree smoothed by postdepositional diffusion.

Like the TOC concentrations, the organic $\mathrm{C} / \mathrm{N}$ ratios fluctuate with depth and do not consistently increase or decrease (Fig. 4). The mean value of $7.7 \pm 1.4$ indicates that the organic matter in these sediments originates predominantly from marine sources (Premuzic et al. 1982; Emerson and Hedges 1988; Jasper and Gagosian 1990; Meyers 1994; Prahl et al. 1994). In general, marine organic matter is considered more susceptible to in situ oxidation in marine sediments than is the more refractory organic matter derived from land plants (Lallier-Vergès et al. 1993). Degradation of organic matter in organic-carbonpoor sediments tends to lower $\mathrm{C} / \mathrm{N}$ ratios as nitrogenous compounds break down to produce ammonia, which is retained by clay minerals, and the $\mathrm{CO}_{2}$ released by
Fig. 3 Concentrations of calcium carbonate, alkalinity, calcium, and magnesium in sediment samples from site 976 . Dissolved inorganic carbon $\delta^{13} \mathrm{C}$ values reflect oxidation of isotopically light organic matter and microbial reduction of dissolved $\mathrm{CO}_{2}$. Sediment depths are given in meters below seafloor (mbsf)

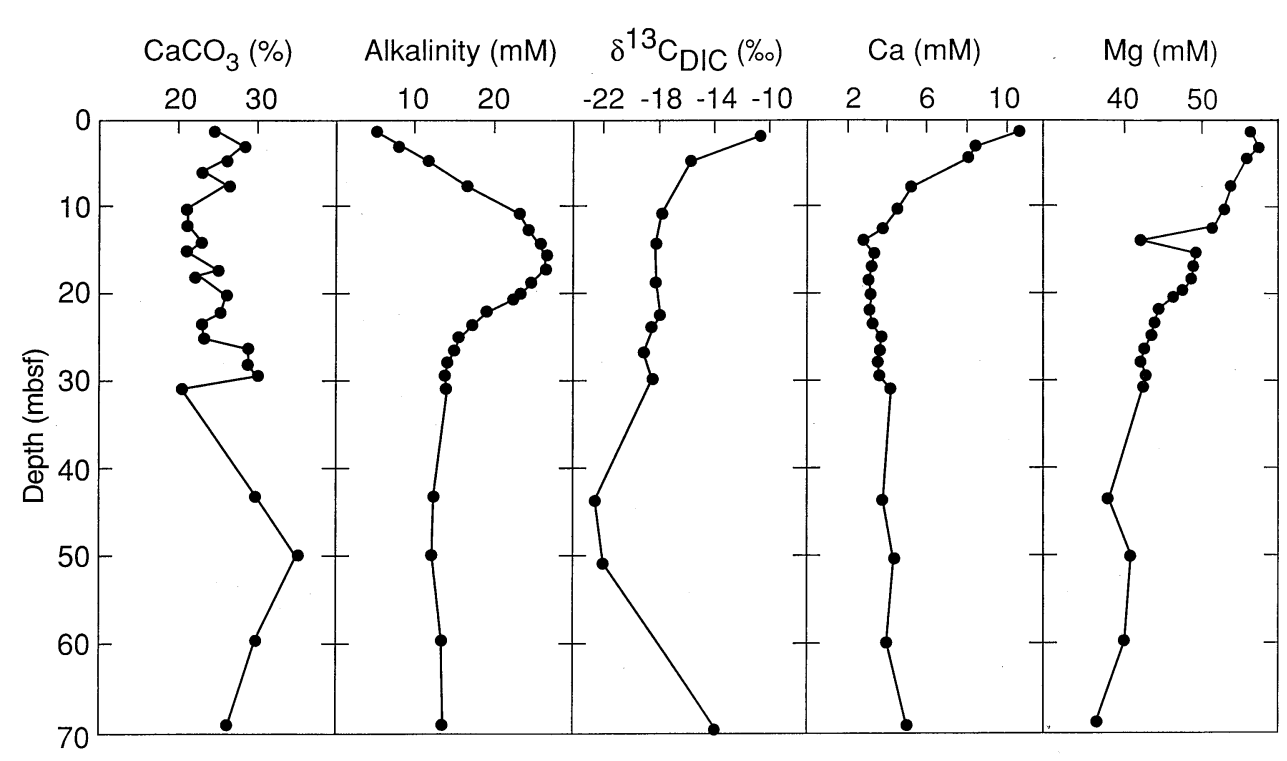




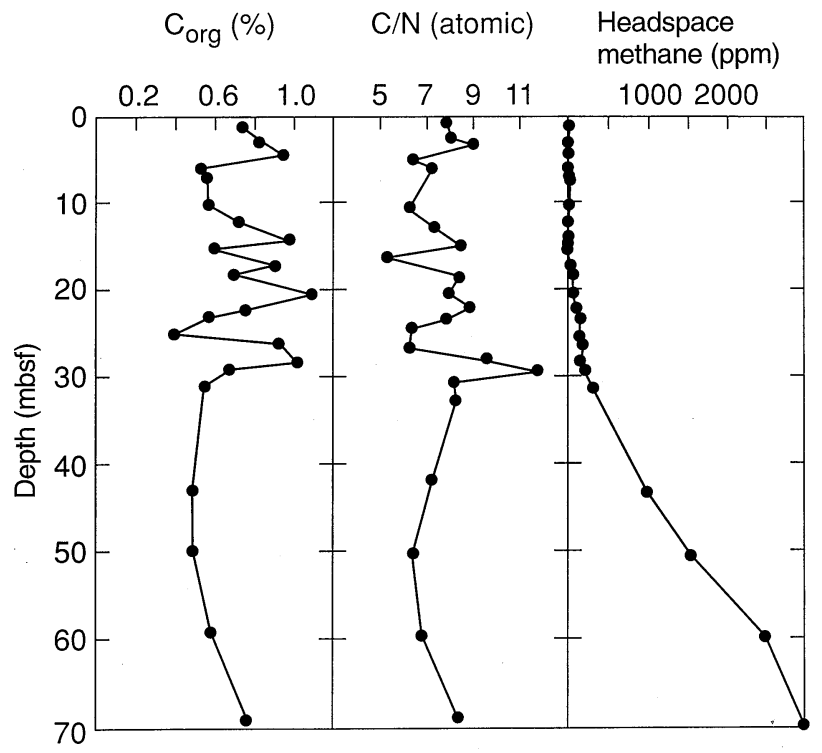

Fig. 4 Concentrations of total organic carbon, atomic organic $\mathrm{C} / \mathrm{N}$ ratios, and concentrations of headspace methane in sediment samples from site 976. Methane concentrations begin to rise after interstital sulfate is depleted. Sediment depths are given in meters below seafloor (mbsf)

oxidation of organic carbon escapes (Müller 1977). The amounts of organic matter present in the sediments on the Alboran Margin are evidently sufficient to mask this diagenetic effect, inasmuch as $\mathrm{C} / \mathrm{N}$ ratios do not respond to the significant variations in ammonia concentrations (Fig. 2).

\section{Methanogenesis}

In sediments devoid of interstitial sulfate but containing metabolizable organic matter, methanogenesis becomes important. This process has two stages in which a consortium of microorganisms first convert the various forms of organic matter into short-chain alcohols and acids, $\mathrm{CO}_{2}$, and $\mathrm{H}_{2}$. In the second stage, some of these products are converted to $\mathrm{CH}_{4}$ by a metabolically limited group of obligate anaerobic microbes (Mechalas 1981; Whiticar 1996). The general reactions that represent the production of methane in the second stages are:

$$
\begin{aligned}
& \mathrm{CH}_{3} \mathrm{COOH} \rightarrow \mathrm{CH}_{4}+\mathrm{CO}_{2} \text { (acetic acid fermentation) } \\
& \mathrm{CO}_{2}+4 \mathrm{H}_{2} \rightarrow \mathrm{CH}_{4}+2 \mathrm{H}_{2} \mathrm{O}\left(\mathrm{CO}_{2}\right. \text { reduction) }
\end{aligned}
$$

Concentrations of headspace methane begin to increase in sediments below 20 mbsf (Fig. 4). It is not until this subbottom depth that interstitial sulfate, an electron acceptor that enables organic matter oxidation, is depleted (Fig. 2). The appearance of methane in the interstitial waters of deep-sea sediments generally indicates methanogenic fermentation of organic matter, but methane can also originate from the thermal breakdown of organic matter in deeper sediments and upward migration to shallower levels (Claypool and Kvenvolden 1983). High methaneethane ratios and the absence of higher-molecular-weight hydrocarbon gases site 976 (Comas et al. 1996) indicate that the gas is microbial, as opposed to thermal in origin. The source of the methane is probably from in situ microbial reduction of the $\mathrm{CO}_{2}$ produced from oxidation and fermentation of the marine organic matter present in this turbiditic unit. The microbial reduction of $\mathrm{CO}_{2}$ has a kinetic isotope effect that discriminates against ${ }^{13} \mathrm{C} \mathrm{CH}_{4}$ so produced is isotopically light, and the residual $\mathrm{CO}_{2}$ is isotopically heavier (Whiticar 1996). The increase in $\delta^{13} \mathrm{C}$ of interstitial dissolved inorganic carbon observed by Böttcher et al. (1998) from $-22.5 \%$ at $43 \mathrm{mbsf}$ to $-14.0 \%$ at $59.5 \mathrm{mbsf}$ (Fig. 3) is consistent with microbial $\mathrm{CO}_{2}$ reduction. Similar microbial production of methane from marine organic matter has previously been inferred from high biogenic gas concentrations in Pilocene-Pleistocene sediments from site 532 on the Walvis Ridge (Meyers and Brassell 1985), in Middle Miocene sediments from site 767 in the Celebes Sea (Rangin et al. 1990), and in Pliocene- Pleistocene turbidites from sites 897 and 898 on the Iberia Abyssal Plain (Meyers et al. 1996).

\section{Summary and conclusions}

Early diagenesis in the rapidly accumulating hemipelagic sediments of the Alboran Margin has produced a succession of changes in interstitial water contents that are sensitive to oxidation-reduction reactions:

- Iron and manganese are reduced in the upper $1.5 \mathrm{~m}$ of the sediment column.

- Alkalinity and phosphate maxima centered on $\sim 15 \mathrm{mbsf}$ indicate the zone of maximum organic matter degradation.

- Sulfate decreases systematically and is depleted in sediments below 20 mbsf.

- Headspace methane first appears at 20 mbsf and increases in deeper sediments.

This succession reflects microbial degradation of the organic matter content of these sediments, using in order, dissolved oxygen, dissolved nitrate, dissolved sulfate, and finally by methanogenesis, and in the process reducing other oxidized species. The elevated sedimentation rate at this site has expanded these redox zones and made the changes more evident than in most sedimentary settings.

Acknowledgments We thank Rick Murray for sharing his knowledge of sediment geochemistry and offering suggestions that helped to improve this paper, Phil Rumford and Chieh Peng for producing the analytical results, and Dale Austin for his graphical skills. The Ocean Drilling Program, funded by the National Science Foundation and IPOD countries, provided us with the special experience of spending two months together at sea during leg 161. 


\section{References}

Berelson WM, Hammond DE, and Cutter GA (1990) In situ measurements of calcium carbonate dissolution rates in deep-sea sediments. Geochimica et Cosmochimica Acta 54:3013-3020

Berner RA (1980) Early Diagenesis - A Theoretical Approach. Princeton, New Jersey: Princeton University Press

Böttcher M, Bernasconi SM, and Brumsack H-J (1998) Carbon and sulfur isotope geochemistry in interstitial waters from Leg 161. In: Zahn R, Comas MC, Klaus A, and Leg 161 Scientific Party. Proceedings ODP, Scientific Results 161: College Station, TX: Ocean Drilling Program

Canfield DE (1993) Organic matter oxidation in marine sediments. In: Wollast R, et al. (Eds.), Interactions of $\mathrm{C}, \mathrm{N}, \mathrm{P}$, and $\mathrm{S}$ in Biogeochemical Cycles. NATO-ARW, pp 333-363

Claypool GE and Kvenvolden KA (1983) Methane and other hydrocarbon gases in marine sediment. Annual Review in Earth and Planetary Science 11:299-327

Comas MC, Zahn R, Klaus A, and Leg 161 Scientific Party (1996) Proceedings ODP, Scientific Results 161: College Station, TX: Ocean Drilling Program

Emerson S and Bender M (1982) Carbon fluxes at the sedimentwater interface of the deep-sea: Calcium carbonate preservation. Journal of Marine Research 39:139-162

Emerson S and Hedges JI (1988) Processes controlling the organic carbon content of open ocean sediments. Paleoceanography $3: 621-634$

Engleman EE, Jackson LL, and Norton DR (1985) Determination of carbonate carbon in geological materials by coulometric titration. Chemical Geology 53:125-128

Froelich PN, Klinkhammer GP, Bender ML, Luedtke GR, Heath GR, Cullen D, Dauphin P, Hammond D, Hartman B, and Maynard V (1979) Early oxidation of organic matter in pelagic sediments of the eastern equatorial Atlantic: Suboxic diagenesis. Geochimica et Cosmochimica Acta 43:1075-1090

Gieskes JM, Gamo T, and Brumsack H (1991) Chemical methods for interstitial water analysis aboard JOIDES Resolution. ODP Technical Note 15, College Station TX: Ocean Drilling Program

Jasper JP and Gagosian RB (1990) The sources and deposition of organic matter in the Late Quaternary Pygmy Basin, Gulf of Mexico. Geochimica et Cosmochimica Acta 54:117-132

Kennett JP (1982) Marine Geology. Englewood Cliffs, New Jersey: Prentice Hall, 813 pp

Lallier-Vergès E, Bertrand P, and Desprairies A (1993) Organic matter composition and sulfate reduction intensity in Oman Margin sediments. Marine Geology 112:57-69

Manheim FT and Sayles FT (1974) Composition and origin of interstitial water of marine sediments based on deep sea drilled cores. In: Goldberg ED (Ed.), The Sea, Vol. 5. New York: Wiley Interscience, pp 527-568

McIver R (1975) Hydrocarbon occurrences from JOIDES Deep Sea Drilling Project. 9th World Petroleum Congress 2:269-280

Mechalas BJ (1981) Pathways and environmental requirements for biogenic gas production in the ocean. In: Kaplan IR (Ed.), Natural Gases in Marine Sediments. New York: Prentice Hall, pp 11-25

Meyers PA (1994) Preservation of elemental and isotopic source identification of sedimentary organic matter. Chemical Geology $144: 289-302$
Meyers PA and Brassell SC (1985) Biogenic gases in sediments deposited since Miocene times on the Walvis Ridge, South Atlantic Ocean. In: Caldwell DE, Brierly JA, and Caldwell CL (Eds.), Planetary Ecology, New York: Wiley, pp 69-80

Meyers PA and Silliman JE (1996) Organic matter in Pleistocene to Quaternary turbidites from sites 897, 898, 899, and 900, Iberia Abyssal Plain. In: Whitmarsh RB, Sawyer DS, Klaus A, and Masson DG (Eds.), Proceedings ODP, Scientific Results 149: College Station, TX: Ocean Drilling Program, pp 305-313

Meyers PA, Silliman JE, and Shaw TJ (1996) Effects of turbidity flows on organic matter accumulation, sulfate reduction, and methane generation in deep-sea sediments on the Iberia Abyssal Plain. Organic Geochemistry 25:69-78

Müller PJ (1977) C/N ratios in Pacific deep-sea sediments: Effect of inorganic ammonium and organic nitrogen compounds sorbed by clays. Geochimica et Cosmochimica Acta 41:765-776

Prahl FG, Ertel JR, Goñi MA, Sparrow MA, and Eversmeyer B (1994) Terrestrial organic carbon contributions to sediments on the Washington margin. Geochimica et Cosmochimica Acta $58: 3055-3048$

Premuzic ET, Benkovitz CM, Gaffney JS, and Walsh JJ (1982) The nature and distribution of organic matter in the surface sediments of world oceans and seas. Organic Geochemistry 4:63-77

Pruysers PA, de Lange GJ, Middelburg JJ, and Hydes DJ (1993) The diagenetic formation of metal-rich layers in sapropel-containing sediments in the eastern Mediterranean. Geochimica et Cosmochimica Acta 57:527-536

Rangin C, Silver E, von Breymann MT, et al. (1990) Site 767. In: Rangin C, Silver E, et al. (Eds.), Proceedings ODP, Initial Results 124, College Station, TX: Ocean Drilling Program, pp 121-193

Schulz HD, Dahmke A, Schinzel U, Wallman K, and Zabel M (1994) Early diagenetic processes, fluxes, and reaction rates in sediments of the South Atlantic. Geochimica et Cosmochimica Acta $58: 2041-2060$

Thomson J, Higgs NC, Croudace IW, Colley S, and Hydes DJ (1993) Redox zonation of elements at an oxic/post-oxic boundary in deep-sea sediments. Geochimica et Cosmochimica Acta 57:579-595

Torii M (1997) Low-temperature oxidation and subsequent downcore dissolution of magnetite in deep-sea sediments, ODP leg 161 (western Mediterranean). Journal of Geomagnetism and Geoelectricity 49: 1233-1245

Verardo DJ, Froelich PN, and McIntyre A (1990) Determination of organic carbon and nitrogen in marine sediments using the Carlo Erba NA 1500 analyzer. Deep-Sea Research 37:157-165

von Breymann MT, Swart PK, Brass GW, and Berner U (1990) Pore-water chemistry of the Sulu and Celebes seas: Extensive diagenetic reactions at sites 767 and 768 . In: Silver EA, Rangin C, von Breymann MT, et al. (Eds.), Proceedings ODP, Scientific Results 124, College Station TX: Ocean Drilling Program, pp 203-215

Whiticar MJ (1996) Isotope tracking of microbial methane formation and oxidation. Mitteilungen International Vereinegung Limnologie $25: 39-54$

Wilson TRS, Thomson J, Hydes DJ, Colley S, Culkin F, and Sørenson J (1986) Oxidation fronts in pelagic sediments: Diagenetic formation of metal-rich layers. Science 232: 972-975 